\title{
Fish growth and health aspects of sea bass (Dicentrarchus labrax) reared in standard vs. high rate algal pond recirculation systems
}

\author{
Ivona Mladineo $^{1, a}$, Ivana Bočina ${ }^{2}$, Cyrille Przybyla ${ }^{3}$, Julie Fievet ${ }^{3}$ and Jean-Paul Blancheton ${ }^{3}$ \\ 1 Laboratory of Aquaculture, Institute of Oceanography \& Fisheries, POB 500, 21000 Split, Croatia \\ ${ }^{2}$ Faculty of Science, University of Split, Teslina 12, 21000 Split, Croatia \\ 3 IFREMER, Station de Palavas, chemin de Maguelone, 34250 Palavas les Flots, France
}

Received 13 October 2010; Accepted 12 March 2010

\begin{abstract}
Recirculation aquaculture system (RAS) is the type of land-based aquaculture production that interferes the least with the environment, particularly due to low effluent volume and overall water requirement. Water reuse, sometimes limited by the accumulation of waste products excreted by fish, can be improved by incorporating another biotechnical component in the form of high rate algal pond (RAS+HRAP), thus adding to the economy and self sustainability of the system. Our goal was to evaluate whether rearing fish for 1 year in a RAS or RAS+HRAP led to differences in fish production and health, by assessing: (1) fish growth; (2) impact on the morphological structure of sea bass target tissues (liver, kidney, and spleen); (3) susceptibility to monogenean parasites; (4) resistance to pathogen challenge with Listonella anguillarum; and (5) total blood protein. Over the one-year experimental period, sea bass showed no statistical differences in any parameter evaluated, suggesting that there was a satisfactory purification rate in the RAS+HRAP system.
\end{abstract}

Key words: Health / High rate algal pond / Recirculation / Sea bass

\section{Introduction}

Aquaculture is an important provider of relatively cheap and abundant animal protein for the increasingly demanding and growing world food market. However, availability of feed resources, access to water of appropriate quality and acceptable waste management remain challenges to the future growth and expansion of aquaculture. One of the solutions that could enable sustainable exploitation of environmental resources is recirculation aquaculture systems (RAS). They are believed to be the type of land-based aquaculture production that interferes the least with the environment, particularly due to low effluent volume and overall water requirements. RAS has proved itself to be economically feasible in several countries, permitting an overall control of the production process, including effluents and biosecurity. However, water reuse can be limited by accumulation of waste products excreted by fish, such as carbon dioxide, ammonia-nitrogen and particulate and dissolved fecal solids (Lemarié and Toften 2003). A way to solve this problem is the incorporation of another biotechnical component in the form of a high rate algal pond (HRAP)

\footnotetext{
${ }^{a}$ Corresponding author: mladineo@izor.hr
}

(Pagand et al. 2000a). A HRAP is obtained by adding different types of macro algae, mainly Ulva, Enteromorpha, Asparagopsis armata (Falkenbergia) and Cladophora, that can develop in the pond and play a role in the absorption of significant quantities of dissolved nutrients from the effluent. Macro algae trap inorganic and organic nutrients, with a preference for ammonium ions, and store them in the form of amino acids and pigments. Macro algae can thus be used to improve nutrient reclamation and clean effluents (Jones 1999). In an environment such as this, micro algae also grow and can occasionally be the only type of algae to develop.

Biological responses of fish maintained in RAS compared with those grown in flow-through systems (FTS) have been the object of previous studies (Schmitt and Dethloff 2000; Metaxa et al. 2006). These investigations mainly focused on enzymatic activity of biomarkers, like ethoxyresorufin- $O$ deethylase (EROD), superoxide dismutase (SOD) and liver protein (LP), and on other factors including fish growth and concentrations of heavy metals. Statistically significant differences were found between the two systems (Deviller et al. 2005), pointing particularly towards improved product quality and safety for the final consumer (Deviller et al. 2005; Metaxa et al. 2006). Although some advances have been made in this 
field, there is still no information on the long-term effect of RAS, with or without an algal pond, on fish health. Likewise, only a few parasitology surveys have been undertaken to elucidate parasitic loads in RAS, all of which suggest that such systems increase proliferation of certain parasitic groups like Myxozoa and Protozoa (Madsen et al. 2000; Palenzuela 2006; Sitjà-Bobadilla et al. 2005). In this study we considered the potential of two sustainable recirculation systems, with the goal of assessing whether 384 days of rearing in RAS and RAS+HRAP conditions led to any differences in fish production and health. In this study we assessed: (1) fish growth performances; (2) impact on the morphological structure of sea bass target tissues (liver, kidney and spleen); (3) susceptibility to monogenean parasites assessed through prevalence and abundance; (4) resistance to pathogen challenge with Listonella anguillarum; and (5) total blood protein.

\section{Materials and methods}

\subsection{Experimental rearing systems}

Six hundred European sea bass (Dicentrarchus labrax) were maintained in two experimental rearing systems from 10 September 2006 until 8 October 2007: a recirculation aquaculture system (RAS, total volume $5 \mathrm{~m}^{3}$ ) and a RAS connected to a $6 \mathrm{~m}^{3}$ high-rate algal pond (RAS+HRAP). These systems were equipped with 3 self-cleaning fish tanks of $1 \mathrm{~m}^{3}$ each, with a water replacement rate of $1 \mathrm{~m}^{3} \mathrm{~h}^{-1}$. The temperature and $\mathrm{pH}$ in the tanks were adjusted daily to remain within the ranges of $17 \pm 0.6{ }^{\circ} \mathrm{C}$ and $\mathrm{pH} 7.6 \pm 0.3$, respectively. Previous observations in the RAS were used as a basis to calculate the ideal temperature in order to have the fish (from a starting weight of $210 \mathrm{~g}$ ) double their weight within a 1-year period (e.g. $22^{\circ} \mathrm{C}$ for 5 months, $4{ }^{\circ} \mathrm{C}$ for 4 months, etc.). Photoperiod was 16 hours of light per day at an intensity of 450 lux. The dissolved oxygen concentration was maintained at up to $90 \%$ saturation in the tank outlet. Daily water replacement in both systems was adjusted according to the quantity of ingested food, in order to maintain constant and equivalent RAS and RAS+HRAP closure ratio: $R_{\text {Newwater/Ingestedfood }}=2$. For the RAS system, renewal water was a mixture of seawater and the freshwater needed for cleaning the mechanical filter. Freshwater entered the system when the drum filter washed the mesh, but its quantity was small relative to the system volume and was measurable by flux measurer: it therefore did not affect growth in the system. For the RAS+HRAP system, renewal water was a mixture of seawater, the freshwater needed for the mechanical filter and water treated by the HRAP loop. The water volume treated by the HRAP component was $15 \%$ of the RAS volume per day on average. The algal pond was outdoors and the algal mass, which grew spontaneously, changed with the seasons.

The recirculated treatment loop of the RAS $\left(6-10 \mathrm{~m}^{3} \mathrm{~h}^{-1}\right)$ consisted of a drum filter $(30 \mu \mathrm{m})$; a storage and pumping tank, where $\mathrm{pH}$ was maintained by adding $\mathrm{NaOH}$ $\left(210 \mathrm{ml} \mathrm{day}^{-1}\right)$ and temperature regulated by heat-exchanger; an UV-disinfection unit $\left(33 \mathrm{~mJ} \mathrm{~cm} \mathrm{~cm}^{-2}\right)$; a submerged nitrifying biofilter $\left(0.7 \mathrm{~m}^{3}\right)$; a degassing unit; and an oxygenation device $\left(6 \mathrm{~L} \mathrm{~min}^{-1}\right)$. Each tank was equipped with particle trap $(23 \mathrm{~L})$

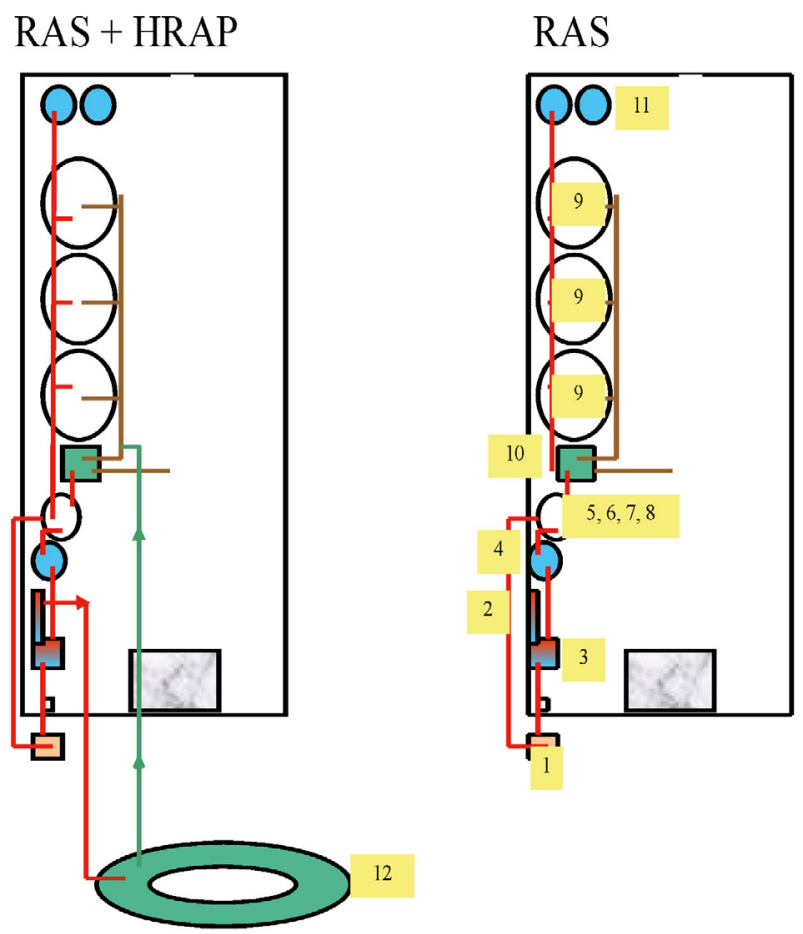

Fig. 1. Schematic representation of recirculation aquaculture systems (RAS) and RAS+HRAP experimental systems at IFREMER, France; 1: Pump; 2: UV reactor; 3: Heat exchanger; 4: Biofilter; 5: $\mathrm{CO}_{2}$ extractor; 6: Degassing column; 7: Water distribution storage tank; 8: Effluent storage tank; 9: Rearing tank $\left(1 \mathrm{~m}^{3}\right)$; 10: Mechanical filter; 11: Sand filter; 12: High rate algal pond.

for the removal of faeces, and daily quantification of uneaten feed. For the HRAP, a part of the effluent $\left(0.45-1 \mathrm{~m}^{3} \mathrm{~h}^{-1}\right)$ was taken before the biological filter inlet and treated outdoors in the HRAP, as described by Pagand et al. (2000b). After 4 to 12 days' residence time in the HRAP, the treated effluent was collected in a small storage tank $(90 \mathrm{~L})$ and pumped back to the system through the inlet of the particle traps, in order to be settled before the drum filter filtration $(30 \mu \mathrm{m})$. Micro algae biomass was maintained in the HRAP with the HRAP inlet water flow varying between 0.5 to $1.5 \mathrm{~m}^{3}$. A schematic representation (Fig. 1), and further technical details are described in an earlier publication (Deviller et al. 2004).

\subsection{System control and sample analysis}

Replacement water flow was checked daily and adjusted when necessary. $\mathrm{NaOH}(1 \mathrm{~N})$ was added to both systems by a setting pump, 3 times 5 min day ${ }^{-1}$, to maintain $\mathrm{pH}$ 7.5. HRAP temperature, $\mathrm{pH}$, and salinity were measured every morning at 9:00 am.

Water of both systems was sampled twice a week at 9:00 am. For RAS, $30 \mathrm{ml}$ of water were collected at the inlet of the biofilter (considered as the outlet of the tank and the inlet of the HRAP) and at the outlet of the biofilter, for the assessment of the biofilter nitrification activity. For RAS+HRAP, $30 \mathrm{ml}$ of water were collected at the outlet of the HRAP (considered as the inlet of the RAS in the RAS+HRAP system) 
MORTALITY (\%)
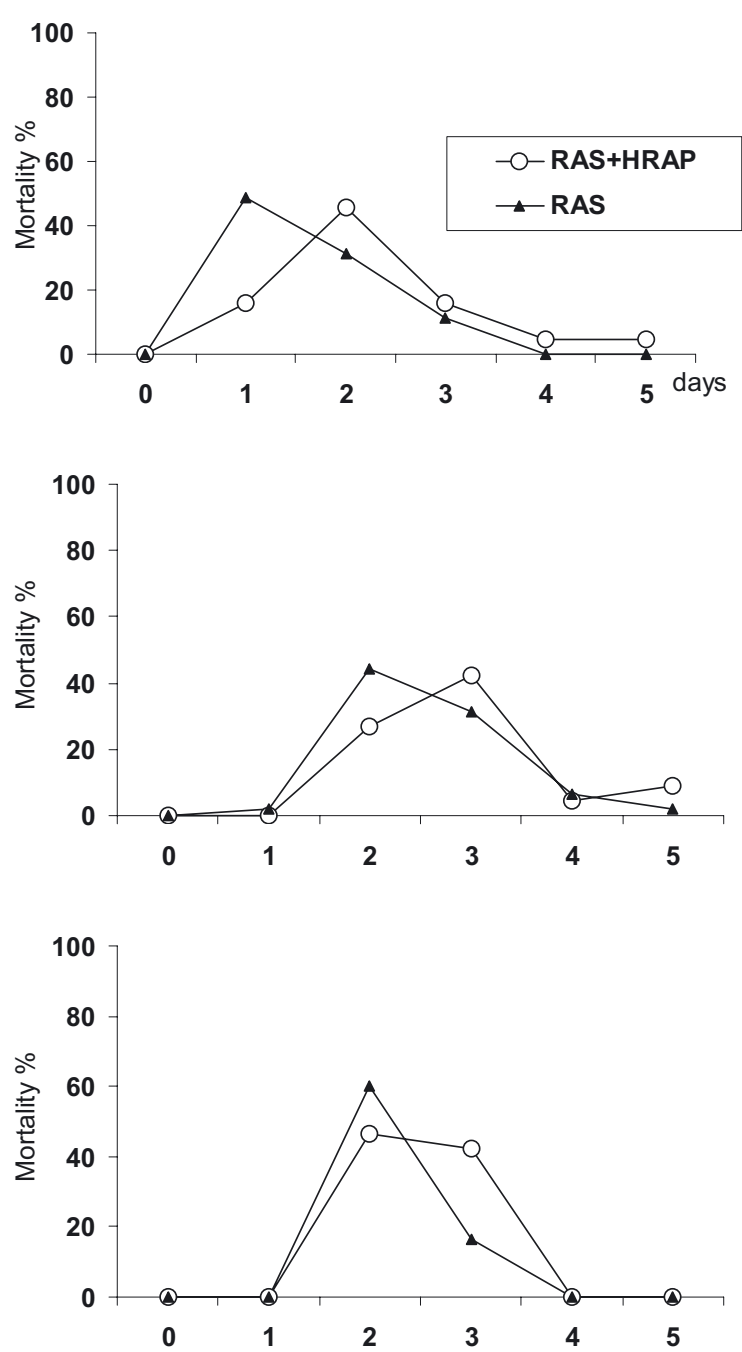

CUMULATIVE MORTALITY (\%)
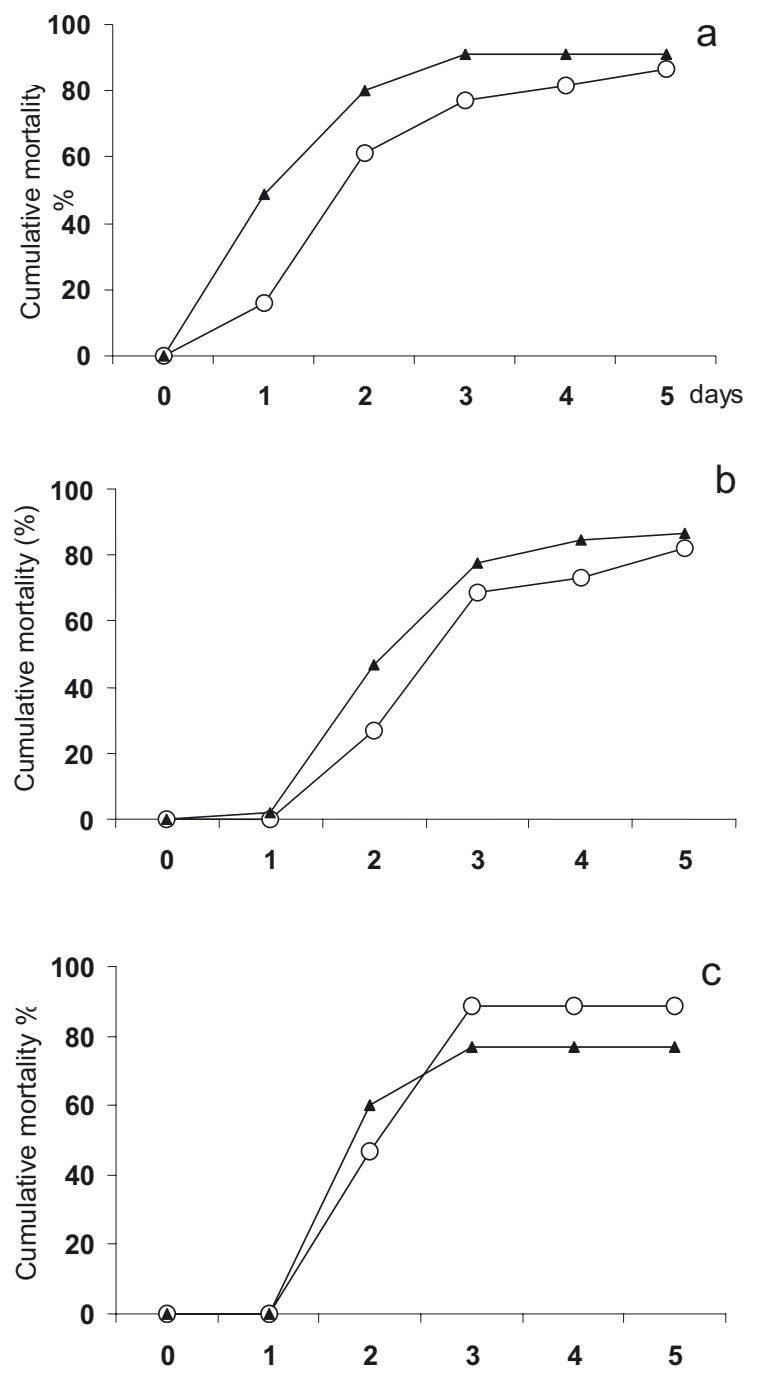

Fig. 2. Mortality (\%) and cumulative mortality (\%) per day in a recirculation aquaculture systems (RAS) compared to a RAS+HRAP, after Listonella anguillarum intraperitoneal challenge; a: with $6 \times 10^{6}$ colony forming units; b: with $2 \times 10^{6}$ colony forming units; c: with $0.5 \times 10^{6}$ colony forming units.

for the assessment of HRAP activity. All the water samples were filtered through glass-fiber filters (GF/C Whatmann $\left.{ }^{\circledR}\right)$ and analyzed with a Technicon Autoanalyser II. Total ammonia nitrogen (TAN) concentration was measured using the method described by Solorzano (1969). Nitrites $\left(\mathrm{NO}_{2}\right)$ were measured by the molecular absorption method described by Bendschneider and Robinson (1952), and nitrates $\left(\mathrm{NO}_{3}\right)$ were measured by the same method after nitrite reduction on a cadmium column (Wood et al. 1967). The sum of these three components is equal to the dissolved inorganic nitrogen (DIN). Determination of phosphates $\left(\mathrm{PO}_{4}^{3-}\right)$ was carried out using the spectrometric method (AFNOR NF T90-023) (Murphy and Riley 1962). The mean values of water nutrients and fish performances were tested for significant differences between the values at beginning and end of experiment, using a parametric t-test $(* p<0.05$ and $* * p<0.01)$ after a normality test and an equal variance test for homoscedasticity (Fisher test), using Microsoft Excelstat office 2000 SR-1 standard package.
Analysis of water quality parameters in RAS and RAS+HRAP systems is given in Table 1.

\subsection{Fish maintenance and sampling}

European sea bass (Dicentrarchus labrax) weighing $205.0 \pm 15.3 \mathrm{~g}$ were acquired from a commercial farm. In order to reduce the variability of the immune response and growth performances, fish were obtained as a filial generation from a single broodstock. For the experiment, fish were randomly distributed between the three tanks, with 100 fish per tank at a density of $20.2 \pm 0.8 \mathrm{~kg} \mathrm{~m}^{-3}$. Fish density $D_{f}\left(\mathrm{~kg} \mathrm{~m}^{-3}\right)$ was calculated using: $D_{f}=\mathrm{wN} /\left(1000 \times V_{t}\right) \mathrm{s}$, where $V_{t}$ is the volume of the rearing tank $\left(\mathrm{m}^{3}\right), N$ number of the fish in the tanks and $w$ the average fish individual weight. The specific growth rate SGR $\left(\%\right.$ day $\left.^{-1}\right)$ was calculated using: SGR $=\left[\ln \left(w_{f}\right)-\right.$ $\left.\ln \left(w_{i}\right)\right] \times 100 \mathrm{t}^{-1}$, where $w_{i}$ is the initial average weight $(\mathrm{g})$, 
Table 1. Water quality parameter analysis in recirculation aquaculture systems (RAS) and RAS+ high rate algal pond (HRAP) systems (twice a week, 9:00 am).

\begin{tabular}{|c|c|c|}
\hline & RAS & RAS + HRAP \\
\hline $\mathrm{T}\left({ }^{\circ} \mathrm{C}\right)$ & $16.9 \pm 0.6$ & $17.0 \pm 0.6$ \\
\hline Salinity & $21.5 \pm 4.6$ & $20.0 \pm 5.6$ \\
\hline $\mathrm{pH}$ & $7.5 \pm 0.3$ & $7.6 \pm 0.3$ \\
\hline Lagoon water $\left(\mathrm{m}^{3}\right.$ day $\left.^{-1}\right)$ & 0 & $0.8 \pm 0.2$ \\
\hline Sea water $\left(m^{3}\right.$ day $\left.^{-1}\right)$ & $0.9 \pm 0.3$ & $0.34 \pm 0.3$ \\
\hline Closure ratio $\mathrm{R}\left(\mathrm{m}^{3} \mathrm{~kg}^{-1}\right)$ & $2.2 \pm 0.9$ & $2.1 \pm 0.9$ \\
\hline $\mathrm{N}-\mathrm{NH}_{4}\left(\mathrm{mg} \mathrm{L}^{-1}\right)$ & $0.14 \pm 0.05$ & $0.15 \pm 0.04$ \\
\hline$* * \mathrm{~N}-\mathrm{NO}_{3}\left(\mathrm{mg} \mathrm{L}^{-1}\right)$ & $14.2 \pm 4.24$ & $19.4 \pm 7.26$ \\
\hline$* * \mathrm{~N}-\mathrm{NO}_{2}\left(\mathrm{mg} \mathrm{L}^{-1}\right)$ & $0.04 \pm 0.19$ & $0.06 \pm 0.03$ \\
\hline$* \mathrm{~N}-\mathrm{CO}\left(\mathrm{NH}_{2}\right)_{2}\left(\mathrm{mg} \mathrm{L}^{-1}\right)$ & $0.04 \pm 0.02$ & $0.06 \pm 0.06$ \\
\hline $\mathrm{P}_{-} \mathrm{PO}_{4}\left(\mathrm{mg} \mathrm{L}^{-1}\right)$ & $0.84 \pm 0.38$ & $0.97 \pm 0.56$ \\
\hline
\end{tabular}

$w_{f}$ final average weight $(\mathrm{g})$, and $t$ time (days). The biomass increase during the 384 days of the experiment was compensated by fish sampling during the experiment. At the end of the experiment, fish density was $25.4 \pm 2.9 \mathrm{~kg} \mathrm{~m}^{-3}$. The fish quickly acclimated to the tactile trigger of the self-feeders, described in Covès et al. (1998), and were fed the commercial sea bass diet Le Gouessant, Extra-Natura ${ }^{\circledR}, 4.0 \mathrm{~mm}$, which has an average composition of $43-45 \%$ proteins, $20 \%$ fat, $7.6 \%$ ash, $2.5 \%$ crude fibre and $1.04 \%$ phosphorus. The non-ingested food (NIF) was collected in the particle traps and measured every morning before filling the self-feeders. The daily ingested food (DIF, in $\mathrm{g} \mathrm{day}^{-1}$ fish) was calculated using: DIF = (DF$\mathrm{NIF}) /\left[t\left(N_{i}+N_{f}\right) / 2\right]$, where DF is distributed food (g), NIF noningested food $(\mathrm{g}), N_{i}$ and $N_{f}$ initial and final number of fish in the tanks, respectively, and $t$ time (day). The food conversion ratio, FCR, was calculated using: FCR $=(\mathrm{DF}-\mathrm{NIF}) /\left[\left(w_{f} \mathrm{x} N_{f}\right)-\right.$ $\left(w_{i} \times N_{i}\right)$ ]. No mortality was observed during the experimental rearing period. During the experiment, the weight $(\mathrm{g})$ of all fish was measured on days 103, 209 and at the end of the experiment, on day 384. For this purpose, fish were anaesthetized after 24 h-starvation, using essential clove oil (Eugenol ${ }^{\circledR}$ ) at a concentration of $30-40 \%$.

\subsection{Parasitological examination}

Gill arches of 30 fish from each rearing system were dissected at the beginning and end of the experiment (total $N=$ 60) and observed under the stereomicroscope for the presence of Diplectanum aequans (Monopisthocotylea, Trematoda). A number of individual parasites were fixed under coverslip pressure, stained with Borax carmine and mounted in Canada balsam for identification. Parasites were counted on each gill arch and prevalence and abundance were calculated according to Bush et al. (1997). Briefly, prevalence is the number of hosts infected with one or more individuals of a particular parasite species, divided by the number of hosts examined for that parasite species, expressed as a percentage. Abundance is the number of a particular parasite in/on a single host, regardless of whether or not the host is infected. The difference in parasite load was calculated by two-tailed independent sample Student t-test using STATISTICA 6 software, after transformation of abundance data by logarithmic transformation to correct nonhomogeneous variance (Krebs 1998).

\subsection{Histology and Transmission Electron Microscopy (TEM)}

Spleen, kidney and liver tissue of fish reared in RAS and RAS+HRAP $(N=30$ each) was sectioned at the beginning of the experiment and after 384 days. Tissue was fixed in Davidson fixative and processed for routine histological preparation. Tissue sections were embedded in Histowax, cut at $6 \mu \mathrm{m}$, and stained with hematoxylin-eosin.

Photographs were taken using an Olympus C0404 camera and processed using DP-soft data-processing software.

Fifteen small randomly-selected fragments of gill filament infected by monogenean $D$. aequans were collected, in addition to target tissue, and fixed in $3.5 \%$ paraformaldehyde and $3 \%$ glutaraldehyde in $0.1 \mathrm{M} \mathrm{PBS}$ (phosphate buffer solution). Tissue was postfixed in $1 \%$ osmiumtetroxide for $1 \mathrm{~h}$, then dehydrated in an ascending series of acetone and embedded in Durcopan resin (Sheehan and Hrapchak 1980). Semi-thin sections of $0.5 \mu \mathrm{m}$ were stained with methylene blue and examined under a Olympus BX41 light microscope. Ultrathin sections $(0.05 \mu \mathrm{m})$ were made from the chosen area of interest and stained with uranyl acetate and lead citrate (Reynolds 1963). The ultrathin sections were examined with an electron microscope FEI Morgagni 268D.

The incidence of morphological changes in TEM sections was calculated as the number of sections with changes divided by the number of total sections examined $(N=15)$, expressed as a percentage. The incidence of changes is given in parenthesis only for changes that were observed in less then $100 \%$ of cases. The tissue was considered changed if changes were present in 30 cells sectioned through the nucleus from three different sites per section.

\subsection{Pathogenicity challenge}

At the end of the experiment, fish from the RAS $(572.8 \mathrm{~g} \pm$ 16.2) and RAS+HRAP (541.8 $\mathrm{g} \pm 16.5)$ were exposed to three pathogen challenges. Fifteen fish per system (total 45) were inoculated in the abdominal cavity with a suspension of representative Listonella anguillarum V62 strain in 1.5\% peptone (Breuil and Haffner 1989) and stocked in a pathogen-free area. Three challenges were made at decreasing doses of the pathogen: $6 \times 10^{5}, 2 \times 10^{5}$ and $0.5 \times 10^{5}$ colony forming units (CFU). The doses tested were chosen based on empirical observation; since, with the first two doses, mortality intensity was too high over a short period of time, the third dose was made 12 and 4 fold less in comparison with the first and second doses, respectively. The water temperature was maintained at $20^{\circ} \mathrm{C}$ during the pathogenicity test, and mortality was monitored during 7 days.

For the total blood protein measurement, blood was sampled from the caudal artery of 9 fish in each system (in triplicate per system, $N$ total fish $=54$ ) without anesthesia at the end 
Table 2. Initial and final weight of fish (g), their specific growth rate $\left(\mathrm{SGR} ; \% \mathrm{day}^{-1}\right)$ and food conversion ratio (FCR) ( \pm SD) in RAS and RAS+HRAP systems.

\begin{tabular}{lcc}
\hline Fish & RAS & RAS+HRAP \\
\hline Initial weight $(\mathrm{g})$ & $210.9 \pm 22.3$ & $199.8 \pm 18.9$ \\
Final weight $(\mathrm{g})$ & $578.8 \pm 16.2$ & $541.7 \pm 16.5$ \\
SGR $\left(\%\right.$ day $\left.^{-1}\right)$ & $0.24 \pm 0.1$ & $0.27 \pm 0.1$ \\
FCR & $2.3 \pm 0.5$ & $2.2 \pm 0.9$ \\
\hline
\end{tabular}

of the experiment. Blood protein concentration was measured by Micro-BCA Assay ${ }^{\circledR}$ in serum after blood was allowed to clot at room temperature, and was then centrifuged 5 minutes at $15000 \mathrm{rpm}$. Supernatant was collected and frozen at $-20{ }^{\circ} \mathrm{C}$ until analysis for total proteins.

\section{Results}

\subsection{Fish growth performances, rearing water quality and HRAP micro algae colonization}

\subsubsection{Fish growth performances}

In RAS, fish entered the rearing system with an average weight of $210.9 \pm 22.3 \mathrm{~g}$, and their final weight after a year was $578.8 \pm 16.2 \mathrm{~g}$. In RAS+HRAP, initial weight was $199.8 \pm$ $18.9 \mathrm{~g}$, and final weight was $541.8 \pm 16.5 \mathrm{~g}$. Specific growth rate was $0.2 \pm 0.1 \% \mathrm{day}^{-1}$ in RAS, and $0.3 \pm 0.1 \% \mathrm{day}^{-1}$ in RAS+HRAP. Food conversion rate was $2.3 \pm 0.5$ in RAS, and $2.2 \pm 0.9$ in RAS+HRAP. No statistical difference was observed for fish growth or food conversion rate between the two systems. Initial and final weights in both systems are shown in Table 2.

\subsubsection{Rearing water quality}

The mean values of rearing water nutrient concentrations were statistically compared between the systems at the beginning and end of the experiment. The concentrations of $\mathrm{N}$ $\mathrm{CO}\left(\mathrm{NH}_{2}\right)_{2}^{*}, \mathrm{~N}_{-} \mathrm{NO}_{2}^{* *}$ and $\mathrm{N}-\mathrm{NO}_{3}^{* *}$ were statistically different at the end of the experiment compared with the beginning ( $p=0.0223, p=0.0023$ and $p=0.0012$, respectively). No statistical difference was evidenced for the functioning of the biological filters between the two systems.

\subsubsection{HRAP micro algae colonization}

The micro algae populations in the HRAP were qualified and quantified during the experiment. Mean abundance (cells per litre) of the dominant species were: diatoms $(7.47 \times$ $10^{8}$ cell $\mathrm{L}^{-1}$, abundance peaking in January, February and April until the end of experiment), Prasinophyceae $(2.53 \times$ $10^{7}$ cell $\left.\mathrm{L}^{-1}\right)$, Chlorophyceae $\left(1.68 \times 10^{7}\right.$ cell L $\mathrm{L}^{-1}$, abundance peak in December), Amphora spp. $\left(6.12 \times 10^{6}\right.$ cell L $^{-1}$, abundance peak in March), and a minor population of Cyanophyceae in the first two months of the experiment.

\subsection{Parasitic infection}

D. aequans (Monopisthocotylea, Trematoda) was the only monogenean species isolated from gills of the reared sea bass, having $100 \%$ prevalence at both the beginning and end of the experiment in both recirculation systems. Gills did not display gross pathology visible to the naked eye, but ultrastructural changes were observed by TEM.

At the beginning of the experiment (in 2006) abundance was $10.2 \pm 7.0$ and $13.0 \pm 8.3$ of D. aequans per fish in RAS and RAS+HRAP, respectively. The t-test showed no statistically significant difference between the two systems ( $p=0.0918$, $p<0.05$ ). At the end of the experiment (in 2007) abundance was $37.8 \pm 25.9$ in RAS, and 66.1 \pm 48.4 in RAS+HRAP, showing no significant difference $(p=0.1229, p<0.05)$. However, a difference was observed between the abundance of parasites at the beginning and end of the experiment in both RAS $(p=0.00006, p<0.05)$ and RAS +HRAP $(p=0, p<0.05)$.

In RAS, the ultrastructural study of gill epithelium at the attachment site of the parasite showed sloughing off, leaving only the central axis of the lamellae, consisting of pillar cells and capillary, intact. Sloughed cells were necrotic with large centrally located nuclei. The nuclear membrane was elevated and swollen, showing disruption and chromatin accumulation on the periphery. Numerous vacuolization sites and enlarged and swollen mitochondria with deteriorated cristae were observed in the cytoplasm. In the close surroundings of the parasite, macrophages with abundant endoplasmic reticulum and melanin granule were found. Mucous cells were elevated in number, accumulating viscous material in their granule, followed by excretion at the apical surface into the lumen. Monogenean squamodisc showed sclerotized thorns supported by parasite connective tissue. Between the thorns, some cells were observed that secreted their vesicle content into the gill tissue. The same changes were seen at the parasite attachment sites in RAS+HRAP, although there were also some additional pathologies. In these cases, thickened neighboring lamellae had fused on the periphery of the monogenean attachment site, where epithelial sloughing off had already occurred. Laterally from the parasite body, secondary lamellae showed apical aneurysm, with the cavity filled with erythrocytes. In one case, transparent spherical bodies of unknown etiology were observed intra-cytoplasmatically in the primary lamellae cell with the pycnotic nucleus. Epithelial cells covering primary lamellae near the attachment site showed intensive extravagination in their apical part. Macrophage accumulation was also observed.

\subsection{Tissue histology and ultrastructure}

In general, liver, spleen and kidney tissue of the sea bass reared in the RAS and RAS+HRAP showed no differences in their morphological structure observed by light or electron microscopy. In both systems, the ultrastructure of liver parenchyma showed signs of adipose infiltration and degeneration. Hepatocytes had a polygonal appearance imposed by the mechanical pressure of accumulated lipid droplets and pale cytoplasm rich in branching rough endoplasmic reticulum (RER). In some cases $(N=70 \%)$ the cell membrane 
vanished, leaving the large condensed nucleus and nucleolus with an edematous appearance and enlarged nuclear pori.

Spleen tissue from both systems showed unchanged typical ultrastructure consisting of pulp with lymphoreticular tissue pervaded with blood sinuses.

In some cases $(N=40 \%)$ stratified nephrocalculi were observed in excretory part of kidney, while macrophages were observed more frequently.

\subsection{Pathogenicity challenge}

Percentages of daily and cumulative mortalities did not vary statistically when 27 fish from each system were inoculated with $6 \times 10^{5}, 2 \times 10^{5}$ or $0.5 \times 10^{5} \mathrm{CFU}$ of active $L$. anguillarum in three trials (Fig. 6). However, fish from the RAS+HRAP system reached the highest percentage of mortality one day later than fish from the RAS when inoculated with $6 \times 10^{5}$ or $2 \times 10^{5} \mathrm{CFU}$.

Analysis of total blood protein in 18 fish from each system revealed that RAS fish had $69.85 \pm 3.79 \mathrm{mg} \mathrm{ml}^{-1}$ of total blood proteins, and RAS+HRAP fish had $68.43 \pm 5.69 \mathrm{mg} \mathrm{ml}^{-1}$, showing no statistical difference.

\section{Discussion}

\subsection{Parasitic infection}

D. aequans is an almost unavoidable parasite in reared sea bass populations, causing mortalities in juvenile fish; its effects are often complicated in the summer months by secondary bacterial infections (Mladineo 2004). It can be isolated throughout the year, even though its occurrence is affected by environmental factors, especially temperature (Cecchini et al. 1997; Cecchini et al. 2001; Mladineo 2005). While both the RAS and RAS+HRAP showed the presence of this parasite, with a significant increase in numbers after one year of experimentation, no statistical evidence was found that one system represented better conditions for parasite propagation than the other. Pathological effects of the parasite assessed at the ultrastructural level were shown to be the same as well. The most common tissue reaction to gill parasites consists of hyperplasia of gill epithelium, resulting in lamellar fusion, telangiectasia, oedema with epithelial separation of basement membranes, necrosis and epithelial desquamation (Dezfuli et al. 2003). However, many other irritants may cause identical lesions, and gill structural damage may merely reflect a generalized stress reaction rather than a toxicant- or parasite-specific response (Haaparanta et al. 1997). In both systems, gill cells responded to the monogenean by proliferation of macrophages and mucus cells, as previously described (Tinsley et al. 2002; Dezfuli et al. 2007; Faliex et al. 2008), but in more advanced stages with high parasitic prevalence, such changes strongly impair gas exchange and gill functionality. On the other hand, changes like lamellar fusion and capillary aneurisms, observed in RAS+HRAP, are frequently connected with high ammonia concentration (Benli et al. 2008; Leasea et al. 2003) or urea (Balasubramanian et al. 1999) in the fishes' environment. Compared to RAS, the pond system showed on average a 1.4 fold increase in urea, nitrate and nitrite concentration that specific algae were not able to efficiently remove from the water.

\subsection{Tissue histology and ultrastructure}

Tissue samples from the two systems did not differ greatly in their histological and ultrastructural architecture, suggesting that any environmental differences between these recirculating systems did not influence tissue composition. This is in accordance with the findings of Deviller et al. (2004; 2005), who found no difference in liver protein level between fish reared in RAS and RAS+HRAP after a one year period, reinforcing the hypothesis of a normal liver condition.

Observed liver alterations are, however, typical for artificially-fed sea bass under intensive conditions. Early reports related these alterations to serious organic perturbations, responsible for inhibition of the development and survival in culture (Mosconi-Bac 1987), but more recent research observed that these anomalies are reversible when the fish are changed to a natural diet, implying that there were effects of altered fatty acid metabolization when dietary lipid content was lower (Mosconi-Bac 1990). In kidney, extracellular depositions of calcium phosphates in form of nephrocalcinosis were present in RAS+HRAP fish. This pathology is highly associated with disturbances in water quality, mainly elevated carbon dioxide levels (Hosfeld et al. 2008) or some pollutants (Lohner et al. 2001). Interestingly, a previous study (Deviller et al. 2005) pointed to increased EROD activity in both recirculation systems due to the traces of pollutant contained in commercial feed, which tend to concentrate in such systems, causing increased liver reaction to xenobiotics. This indicates that the nephrocalcinosis might be related to unbalanced chemical composition of the RAS+HRAP water; more specific research is, however, necessary.

\subsection{Pathogen challenge and total blood proteins}

L. anguillarum is widely used as the challenge pathogen for both marine and freshwater fish species (Huttenhuis et al. 2006; Kettunen and Fjalestad 2006), but it is known that its pathogenicity varies in respect to the physico-chemical and biological conditions (Kotzamanis et al. 2007; Piccininno et al. 1996). Sea bass mortalities arising from $L$. anguillarum challenge and levels of blood proteins were similar in the two experimental systems, indicating that rearing conditions did not greatly influence components of specific and innate immune response involved with the reaction to $L$. anguillarum (Caipang et al. 2009).

\section{Conclusion}

HRAP-treated water did not induce differences in fish growth, fish mortality, monogenean parasite load, total protein levels or resistance to L. anguillarum challenge compared with classic RAS. Tissue ultrastructural changes at the parasitized site of the monogenean trematode did not differ between two systems, and were therefore consistent with previous research. 
Although RAS+HRAP remains a valuable sustainable type of aquaculture, where fish growth performances are no different compared to other systems, more research is required to identify and remedy any shortcomings.

Acknowledgements. This research was conducted as part of the Egide project PEARL ECO-NET 12603QH.

\section{References}

Balasubramanian P., Saravanan T.S., Palaniappan M.K., 1999, Biochemical and histopathological changes in certain tissues of Oreochromis mossambicus (Trewaves) under ambient urea stress. Bull. Environ. Cont. Toxicol. 63, 117-124.

Benli A.C.K., Koksal G., Ozkul, A., 2008, Sublethal ammonia exposure of Nile tilapia (Oreochromis niloticus L.): Effects on gill, liver and kidney histology. Chemosphere 72, 1355-1358.

Benscheneider K., Robinson R.J., 1952, A new spectrophotometric determination of nitrites in seawater. J. Mar. Res. 11, 87-96.

Breuil G., Haffner P., 1989, A field report on Listonella disease of sea bass, (Dicentrarchus labrax) in the south of France. In: Abstract book "Advances in Tropical Aquaculture", Tahiti, 20 February 4 March, 1989.

Bush A.O., Lafferty K.D., Lotz J.M., Shostak A.W., 1997, Parasitology meets ecology on its own terms: Margolis et al. revisited. J. Parasitol. 83, 575-583.

Caipang C.M.A., Brinchmann M.F., Kiron V., 2009, Profiling gene expression in the spleen of Atlantic cod, Gadus morhua upon vaccination with Listonella anguillarum antigen. Comp. Biochem. Physiol. B in press.

Cecchini S., Saroglia M., Berni P., Cognetti Varriale A.M., 1997, Influence of temperature on the life cycle of Diplectanum aequans (Monogenea, Diplectanidae), parasitic on sea bass, Dicentrarchus labrax (L.). J. Fish Dis. 21, 73-75.

Cecchini S., Saroglia M., Cognetti Varriale A.M., Terova G., Sabino G., 2001, Effect of low environmental temperature on embryonic development and egg hatching of Diplectanum aequans (Monogenea, Diplectanidae) infecting European sea bass, Dicentrarchus labrax. Fish Pathol. 36, 33-34.

Covès D., Gasset E., Lemarié G., Dutto G., 1998, A simple way to avoiding feed wastage in European seabass, Dicentrarchus labrax under self-feeding conditions. Aqua. Living Resour. 11, 395-401.

Deviller G., Aliaume C., Nava M.A.F., Casellas C., Blancheton J.-P., 2004, High-rate algal pond treatment for water reuse in an integrated marine fish recirculation system: effect on water quality and sea bass growth. Aquaculture 235, 331-344.

Deviller G., Palluele O., Aliaume C., Asanthi H., Sanchez W., Franco Nava M.A., Blancheton J.-P., Casellas C., 2005, Impact assessment of various rearing systems on fish health using multibiomarker response and metal accumulation. Ecotoxicol. Environ. Safety 61, 89-97.

Dezfuli B.S., Giari L., Konecny R., Jaeger P., Manera M., 2003, Immunohistochemistry, ultrastructure and pathology of gills of Abramis brama from lake Mondsee, Austria, infected with Ergasilus sieboldi (Copepoda). Dis. Aquat. Org. 53, 257-262.
Haaparanta A., Valtonen E.T., Hoffmann R.W., 1997, Gill anomalies of perch and roach from four lakes differing in water quality. J. Fish Biol. 50, 575-591.

Hosfeld C.D., Engevik A., Mollan T., Lunde T.M., Waagbo R., Olsen A.B., Breck O., Stefansson S., Fivelstad S., 2008, Long-term separate and combined effects of environmental hypercapnia and hyperoxia in Atlantic salmon (Salmo salar L.) smolts. Aquaculture 280, 94-108.

Huttenhuis H.B.T., Ribeiro A.S.P., Bowden T.J., Van Bavel C., Taverne-Thiele A.J., Rombout J.H.W.M., 2006, The effect of oral immuno-stimulation in juvenile carp (Cyprinus carpio L.). Fish Shellfish Immunol. 21, 261-271.

Jones A., 1999, Environmental management of aquaculture effluent: development of biological indicators and biological filters (Thesis) http://www.cms.uq.edu.au/marbot/publications.

Kettunen A., Fjalestad K.T., 2006, Resistance to Listonellasis in Atlantic cod (Gadus morhua L.): First challenge test results. Aquaculture 258, 263-269.

Kotzamanis Y.P., Gisbert E., Gatesoupe F.J., Zambonino Infante J., Cahu C., 2007, Effects of different dietary levels of fish protein hydrolysates on growth, digestive enzymes, gut microbiota, and resistance to Listonella anguillarum in European sea bass (Dicentrarchus labrax) larvae. Comp. Biochem. Physiol. A 147, 205-214.

Krebs C.J., 1998, Ecological Methodology, $2^{\text {nd }}$ edn. Addison Wesley Longman, Inc, Menlo Park, CA.

Leasea H.M., Hansenb J.A., Bergmanc H.L., Meyerc J.S., 2003, Structural changes in gills of Lost River suckers exposed to elevated $\mathrm{pH}$ and ammonia concentrations. Comp. Biochem. Physiol. C 134, 491-500.

Lemaire P., Berhaut J., Lemaire-Gony S., Lafaurie M., 1992, Ultrastructural changes induced by benzo[ $[a]$ pyrene in sea bass (Dicentrarchus labrax) liver and intestine: Importance of the intoxication route. Environ. Res. 57, 59-72.

Lohner T.W., Reash R.J., Willet V.E., Fletcher J., 2001, Assessment of tolerant sunfish populations (Lepomis sp.) inhabiting seleniumladen coal ash effluents: 3 . Serum chemistry and fish health indicators. Ecotoxicol. Environ. Safety 50, 225-232.

Madsen H.C.K., Buchmann K., Mellergaard S., 2000, Association between trichodiniasis in eel (Anguilla anguilla) and water quality in recirculation system. Aquaculture 187, 275-281.

Metaxa E., Deviller G., Pagand P., Alliaume C., Casellas C., Blancheton J.-P., 2006, High rate algal pond treatment for water reuse in marine fish recirculation system: Water purification and fish health. Aquaculture 252, 92-101.

Mladineo I., 2005, Parasite communities of Adriatic cage-reared fish. Dis. Aquat. Org. 64, 77-83.

Mladineo I., 2004, Study of monogenean parasites in the Adriatic cage reared fish. Acta Adriat. 45 65-73.

Mosconi-Bac N., 1987, Hepatic disturbance induced by an artificial feed in the sea bass (Dicentrarchus labrax) during the first year of life. Aquaculture 67, 93-99.

Mosconi-Bac N., 1990, Reversibility of artificial feed-induced hepatocyte disturbances in cultured juvenile sea bass (Dicentrarchus labrax): an ultrastructural study. Aquaculture 88, 363-370.

Murphy J., Riley J.P., 1962, A modified single solution method for the determination of phosphate in natural waters. Analyt. Chim. Acta 27, 31-36. 
Pagand P., Blancheton J.-P., Casellas C., 2000a, A model for predicting the qualities of dissolved inorganic nitrogen released in effluents from a sea bass (Dicentrarchus labrax) recirculating water system. Aquacult. Engineer. 22, 137-153.

Pagand P., Blancheton J.-P., Lemoalle J., Casellas C., 2000b, The use of high algal rate ponds for the treatment of the marine effluent from a recirculating fish rearing system. Aquacult. Res. 31, 729736.

Palenzuela O., 2006, Myxozoan infections in Mediterranean mariculture. Parassitologia 48, 27-29.

Piccininno G., Ciuchini F., Adone R., Ceschia G., Giorgetti G., 1996, Morphological, physico-chemical and biological variations in Listonella anguillarum cultured at low osmolarity. New Microbiol. 19, 321-6.

Schmitt C.J., Dethloff G.M., 2000, Biomonitoring of environmental status and trends (BEST) program: selected methods for monitoring chemical contaminants and their effect in aquatic ecosystems U.S. Geological survey, Biological Resources Division, Columbia, (MO): Information and Technical Report USGS/BRD-2000-0005 pp. 81.

Sitjà-Bobadilla A., Padrós F., Aguilera C., Alvarez-Pellitero P., 2005, Epidemiology of Cryptosporidium molnari in Spanish gilthead sea bream (Sparus aurata L.) and European sea bass (Dicentrarchus labrax L.) cultures: from hatchery to market size. App. Environ. Microbiol. 71, 131-139.

Solorzano L., 1969, Determination of ammonia in natural waters by the phenolhypochlorite method. Limnol. Oceanog. 14, 799-801.

Tinsley R.C., Cable J., Porter R., 2002, Pathological effects of Pseudodiplorchis americanus (Monogenea: Polystomatidae) on the lung epithelium of its host, Scaphiopus couchii. Parasitology $125,143-153$.

Wood E.D., Armstrong F.A.J., Richards F.A., 1967, Determination of nitrate in sea water by cadmium-copper reduction to nitrite. J. Mar. Biol. Assoc. UK 47, 23-31. 